\title{
Femtomole per Liter
}

National Cancer Institute

\section{Source}

National Cancer Institute. Femtomole per Liter. NCI Thesaurus. Code C68887.

A unit of concentration (molarity unit) equal to one quadrillionth of a mole (10E-15 mole)

of solute in one liter of solution. 